Check for updates

Newcastle upon Tyne, UK

stokel@gmail.com

Cite this as: BMJ 2021;373:n1645

http://dx.doi.org/10.1136/bmj.n1645

Published: 29 June 2021

\section{Covid-19: The countries that have mandatory vaccination for health workers}

The world is divided over whether doctors and other health workers should have a covid-19 jab to do their jobs. As the UK once again considers the situation, Chris Stokel-Walker looks at the differing perspectives globally

\section{Chris Stokel-Walker freelance journalist}

What would you do to keep your job? It's a question that healthcare workers in Texas were confronted with in April, when local hospital network Houston Methodist required its staff to be vaccinated against SARS-CoV-2. Nearly 25000 employees dutifully lined up to be protected against covid-19, and to protect their patients. More than 150 didn't, and have since either been sacked or resigned. ${ }^{1}$

A court case brought by one of the employees, a former nurse, was dismissed by a district court judge, but the case raised questions about requiring vaccination using products that have not been fully approved by the US Food and Drug Administration. ${ }^{2}$ The employee, meanwhile, has appealed the ruling.

What was once a hypothetical question is now a real one, and not just in the US. Businesses around the world are considering making coronavirus vaccinations mandatory for workers (Morgan Stanley and the publisher Bloomsbury are two major companies to have already made the move). And those on the frontlines of the pandemic are no different.

\section{Global decisions}

In Public Health England's 2019-20 report on seasonal influenza vaccines, there was one eye opening point: one in four healthcare workers did not get a flu vaccine. ${ }^{3}$ And there are indications that roughly the same proportion of people are wary of having covid-19 jabs.

The UK government will make covid vaccination mandatory for care home staff from October, and is considering whether to extend the policy to NHS staff. ${ }^{4}$ Advocates argue that it is not dissimilar to hepatitis $B$ vaccination, which is required by some hospital trusts. ${ }^{5}$ But such policies have never been tested legally. Trusts ask staff to receive the hepatitis $B$ vaccine but, in practice, those who don't are simply taken off duties that could expose them to the disease.

Elsewhere in the world, Saudi Arabia takes perhaps the hardest line: no jab, no job. In May, its government said employees in the public, private, and non-profit sectors must be vaccinated before they can return to work.

It followed Italy, which in March introduced a requirement for health workers, including pharmacists, to be vaccinated before treating patients. Serbia is considering a similar stance.

"The aim of the measure is to protect as much as possible both medical and paramedical staff and those who are in environments that may be more exposed to the risk of infection," the Italian government said in a statement. Those who refuse face suspension without pay for the rest of the year. The government moved after clusters of hospital infections were linked to unvaccinated staff and is designed to combat an endemic anti-vaccination movement in the country.

Most countries are, however, yet to tackle the difficult question and, among those that have, policies differ in terms of the types of worker, situations, and strictness in insisting on vaccination.

In Moscow, two million people in public facing jobs, including frontline health workers, have been told they must be vaccinated by the city's mayor after a spike in cases. Businesses will be monitored to make sure they comply-at least $60 \%$ of employees must have a first dose by 15 July or firms risking being fined.

Ireland hasn't ruled out making covid-19 vaccination mandatory for health workers, but the country's health regulator called it the "most intrusive step" that should only be considered if the risk to patients from unvaccinated health staff was high because of increased community transmission. Some hospital trusts in Ireland have already sent staff who refuse to be vaccinated home on full pay to avoid them being close to patients.

Like the UK, France is paying close attention to care homes. Health minister Olivier Veran made a "solemn appeal" to care workers to get vaccinated to help protect the patients they treat, after data showed those working in care homes had a lower rate of uptake for the jab than the general population-a worry in a country with one of the world's highest rates of vaccine hesitancy.

\section{Carrots and sticks}

The threat of no pay can either be a major incentive or disincentive to act: The BMJ has previously reported on how financial support for those in the US asked to self-isolate encouraged people to take covid-19 tests. ${ }^{6}$ Before then, the sick would stay away from testing sites for fear they'd lose their jobs if asked to self-isolate after a positive test.

In the US, there are plenty of precedents for recommended, rather than forced, vaccination for health and social care workers. Since 1984, the Centers for Disease Control and Prevention has recommended workers take an annual flu vaccine. 
Melvin Sanicas, a vaccinologist at the London School of Hygiene and Tropical Medicine (LSHTM), says that in most parts of the world, people recommend rather than mandate the uptake of influenza vaccines. "For covid-19, it also makes sense," he told The BMJ.

Of course, the high take up of vaccines in healthcare workers is important not just for their protection and the protection of patients but because they are an important source of information about vaccines for others.

Yet it's not as simple as just appealing to this responsibility. Wider factors, including political and religious beliefs, come into play.

At least one study has found that pressure from bosses has a negative effect on the likelihood a healthcare worker will get vaccinated. 7 "Health and social care providers need to offer a space for their staff to have conversations where they feel safe to ask about covid-19 vaccination, and not feel judged and stigmatised for having questions or concerns," says Sadie Bell of LSHTM, who led the study.

In their survey of nearly 2000 UK health and social care workers, every point further up a five point scale workers felt pressured to take the jab resulted in them being $75 \%$ more likely to turn down the offer.

Some have turned down vaccination on religious grounds. That could affect many countries. According to Melissa Leach, director of the Institute of Development Studies, Muslim majority countries and Muslims in countries with high vaccination rates have generally lower rates of uptake, which has been credited to misinformation about what ingredients the vaccine contains (such as whether ingredients are halal or not), as well as distrust of political rules in religiously polarised countries. Indonesia has sought to tackle this by publicly declaring its approved vaccines halal, engaging social media influencers, and prominently featuring high ranking officials getting vaccinated to show the vaccine is safe and endorsed. ${ }^{8}$

But trust is a major factor for religious minorities. Leach, who has studied vaccine hesitancy around the world, points to India.

"Vaccine hesitancy around covid seems to be a particular problem among certain Muslim communities there," she says. That's triggered by the anti-Muslim ruling party who are seen to be foisting vaccines on the population, generating unfounded fears it's a ploy to depopulate Muslims in the country. "It's not about a disbelief in the reality of covid," says Leach, "It's more about lack of trust in government."

Leach believes many fears stem from a feeling of exclusion from the debate and discussion around vaccines, and the political system delivering those vaccines. "Vaccines are delivered by the state, and if people are marginalised from, excluded from, or don't trust those state authorities, then they don't trust that thing," she says.

Research led by Katherine Woolf, associate professor in medical education at University College, London, adds further evidence. In one UK study, she surveyed over 11 ooo health workers, finding $23 \%$ with vaccine hesitancy. 9 "Healthcare workers who were more hesitant about having a covid vaccine's fears were driven by a lack of trust in those making and rolling out vaccines," says Woolf.

"There is obviously variability by context, but our research findings generally support and are supported by research from across several countries."

Woolf is realistic. "There's always a small minority of people you're not going to reach, or whose minds you're not going to change," she says. Even the most persuasive education campaign will never convince everyone. Focusing on those who are persuadable is vital-as is trumpeting the scale and speed of the vaccine programme to date, within and outside the health and social care sectors.

"My guess is that, as the vaccination programme carries on rolling out, the social norms around covid-19 vaccines will become more embedded," says Woolf. "People will see that their friends, their colleagues, and their loved ones have been vaccinated, and have been okay. Levels of hesitancy probably will go down.”

Commissioned, not externally peer reviewed

Competing interests: I have read and understood BMJ policy on declaration of interests and have no relevant interests to declare.

Diamond D. Houston Methodist loses 153 workers who refuse coronavirus vaccines. Washington Post. 22 June 2021. www.washingtonpost.com/health/2021/06/22/houston-methodist-loses153-employees-vaccine-mandate

2 Doshi P. Covid-19 vaccines: in the rush for regulatory approval, do we need more data?BMJ 2021;373:n1244. doi: 10.1136/bmj.n1244 pmid: 34006591

3 Public Health England. Seasonal influenza vaccine uptake in healthcare workers in England: winter season 2019 to 2020. June 2020. www.gov.uk/government/statistics/seasonal-flu-vaccine-uptakein-healthcare-workers-winter-2019-to-2020

4 Dyer C. Covid-19: vaccination to become mandatory for care home staff and could extend to NHS. BMJ 2021;373:n1576. doi: 10.1136/bmj.n1576 pmid: 34140305

5 Wise J. Covid-19: Is the UK heading towards mandatory vaccination of healthcare workers?BMJ 2021;373:n1056. doi: 10.1136/bmj.n1056 pmid: 33883193

6 Stokel-Walker C. Covid-19: Why test and trace will fail without support for self-isolation. BMJ 2021;372:n327. doi: 10.1136/bmj.n327 pmid: 33558221

7 Bell S, Clarke RM, Ismail SA, et al. Covid-19 vaccination beliefs, attitudes, and behaviours among health and social care workers in the UK: a mixed-methods study.Medrxiv2021.04.23.21255971 [Preprint]. 2021www.medrxiv.org/content/10.1101/2021.04.23.21255971v1

8 Baraniuk C. How to vaccinate the world against covid-19. BMJ2021;372:n211. doi: 10.1136/bmj.n211 pmid: 33547042

9 Woolf K, McMamus C, Marting CA, et al. Ethnic differences in SARS-CoV-2 vaccine hesitancy in United Kingdom healthcare workers: results from the UK-REACH prospective nationwide cohort study.medRxiv 2021.04.26.21255788 [Preprint]. 2021www.medrxiv.org/content/10.1101/2021.04.26.21255788v1.full.pdf

This article is made freely available for use in accordance with BMJ's website terms and conditions for the duration of the covid-19 pandemic or until otherwise determined by BMJ. You may use, download and print the article for any lawful, non-commercial purpose (including text and data mining) provided that all copyright notices and trade marks are retained. 